\title{
Strategic Adaptation of Traditional Festivals for the Sustainable Development of the Biodiversity of Local Communities in Ghana
}

\author{
Dickson Adom \\ Department of Educational Innovations in Science and Technology, Kwame Nkrumah University of Science and Technology, \\ Kumasi, Ghana \\ Email: adomdick@yahoo.com
}

How to cite this paper: Adom, D. (2017) Strategic Adaptation of Traditional Festivals for the Sustainable Development of the Biodiversity of Local Communities in Ghana. Open Journal of Social Sciences, 5, 69-94. https://doi.org/10.4236/jss.2017.511006

Received: October 12, 2017

Accepted: November 13, 2017

Published: November 16, 2017

Copyright $\odot 2017$ by authors and Scientific Research Publishing Inc. This work is licensed under the Creative Commons Attribution International License (CC BY 4.0).

http://creativecommons.org/licenses/by/4.0/

\begin{abstract}
Traditional festivals in Ghana are cultural events that are primarily organized to venerate the ancestors while remembering iconic events in the history of ethnic societies. However, due to the deleterious condition of the environment and its biodiversity resources, there is a great potential of tactically tailoring these traditional festivals to halt this wanton destruction while ensuring the sustainable development of biodiversity. This is especially important in local communities where illegal mining activities and deforestation has soared up recently in Ghana. Three traditional festivals in Ghana, namely, the Opemso festival, Papa Nantwi festival and the Apoo festival of some ethnic societies in Ghana were phenomenologically studied in a qualitative research approach with the aim of directly observing and carefully investigating into how the traditional festivals could be used as platforms for achieving environmental sustainability. Sixty-six purposive sampled respondents, some of whom were personally interviewed, while others were interviewed in a Focus Group Discussion were involved in the study. The research revealed after the Interpretative Phenomenological Analysis of the accrued data that traditional festivals, though earmarked for the exhibitions of the rich culture of ethnic societies, they could be harnessed as avenues for the sustainable development of local communities. The study, therefore tasks environmentalists, foresters, biodiversity conservation planners and environmental development agencies to liaise with local communities in mapping out pragmatic environmental sustainability programs to bring to cessation, the environmental malfeasance in Ghana.
\end{abstract}

\section{Keywords}

Festivals, Tradition, Culture, Biodiversity, Sustainable Development, Local Communities 


\section{Introduction}

Traditional festivals serve as avenues for propagating the rich cultural heritage of local communities [1]. These social events are primarily celebrated to advertise and reaffirm the place identities of local communities [2] of which their cultural identities, thus, their norms, beliefs and moral values are vividly espoused during the occasion [3]. These cultural precepts of societies evident in the traditional festivals are particularly couched to sustainably develop the local communities through an enhancement of their venue infrastructures [4], reaffirming their traditional political systems [5], improving their economic condition [6] and more important to this discussion, ensures the enhancement of the environment [1] and protection of the biodiversity [3]. [7] notes that traditional festivals are mostly linked to planting, harvesting and environmental cleansing basically aimed at honoring the ancestors as a bait for their blessings in return. Interestingly, [8] contends that traditional festivals help in revitalizing the indigenous knowledge which has been unjustly negated but are valuable tools for natural resource management. This might explain the often much emphasis placed on the development and conservation of the environment and its biodiversity resources. Of course, traditional festivals promote the ideologies linked to the preservation of the environment and its natural resources [9].

Local people hold the strong belief that the ancestors visit their homeland during festivals to inspect the environment and its natural resources they left in the care of the present generation [10]. Therefore, it is believed by many ethnic societies in Ghana that the ancestors punish or reward members of the society based on how judiciously or wantonly they used the biodiversity resources in their environment [11]. Therefore, during the festival commemoration, environmentally friendly activities are undertaken such as tree planting exercises and removal of all forms of refuse and debris to develop their society while appeasing their deities and ancestors [12]. Thus, [13] advise the management teams of festivals to use the event to sell the innovation and service aspects, one of which is to honor the ancestors through environmentally friendly activities.

The afore-mentioned accounts buttress the view of [14] that festivals are being used in different ways today, aside from their traditional cultural values. Aside from their core purpose and ideas which is to promote the cultural heritage of the host communities, [13] add that festivals serve the interests of stakeholders. They serve as avenues for espousing the policies and developmental agenda of governments, as well as private and public organizations [5]. [7] mentions that traditional festivals are now used as platforms by many societies whereby duty bearers are invited to communicate with the societal members on developmental issues.

However, it is said that the great opportunities for sustainable development that traditional festivals offer remain unexploited by many organizations [1]. These organizations need to liaise with the local communities, especially, the festival organizing teams to intensify other developmental agenda, such as the conservation and sustainable use of biodiversity. [14] advises festival organizing 
teams to be open to adaptations if the traditional festivals they are organizing would be successful. These adaptations would make the traditional festivals earn the support of enterprising organizations. For instance, many institutions in charge of biodiversity and environmental protection would welcome such collaboration where their sustainable and conservatory ideals would be promoted through education and sensitization programs carried out during the festival occasion. The financial support of such institutions would help in the survival of the festival and garnish it, as it were, to meet the taste of the contemporary society. [15] reveals that traditional festivals are aimed at building communities through individual and collective efforts. Such individual and collective efforts on the part of societal members for activities such as tree planting, environmental cleansing activities and a ban on particular flora and fauna species are keen to the development and conservation of the biodiversity resources in the local communities.

Also, [16] opines that there are competitions during festival occasions. These competitions can be tailored to suit the objectives of biodiversity development and conservation in the host communities of the festival. This shows that traditional festivals can be adapted to promote the development of biodiversity in the local regions. Ghana is a country with numerous local communities that host numerous traditional festivals. The various studies on traditional festivals have always emphasized their roles in maintaining the cultural heritage of local communities and promoting the beliefs and customs of local communities [5], maintaining their place identities [2], historical significance [3] and as tourism avenues to boost local economies [1]. The tenet of the study which is of novelty is finding ways of adapting the roles of traditional festivals to help in the sustainable development of the biodiversity of local communities through the promotion of the ideals of conservation and sustainability. This is very important in this age when Ghana is facing a massive decline in its biodiversity resources, with its high forest regions depreciating gradually in its land cover. [17] as cited in [3] estimate about 4\% of the GDP loss of Ghana's economy, which is US\$54 billion to biodiversity depletion. This research is aimed at investigating the possibility of adapting three traditional festivals in Ghana, namely, the Opemso festival of the people of Anyinam Kokofu in the Ashanti Region, the Apoo festival of the people of Techiman in the Brong Ahafo Region and the Papa Nantwi festival of the Asantes of Kumawu in the Ashanti Region. The study was driven by three research questions namely:

1) What are the core purposes and the significance of the traditional festival?

2) What aspects of the traditional festival commemoration assist in the sustainable development of the environment and its biodiversity resources?

3) How can the traditional festivals studied be adapted to promote the sustainable development of the biodiversity in the host local communities?

A thorough investigation into these questions would aid in finding proactive ways of harnessing the celebration of traditional festivals in the three local communities in promoting, sustaining and developing the rich biodiversity re- 
sources in the regions. This would serve as a potent model to streamline the other traditional festivals in Ghana with a catalyst objective of protecting Ghana's biodiversity which is facing a great threat of wanton depletion.

The research has a lot of practical social significance for the host communities. The research would heighten the value of environmental sustainability education during the festival event. This would aid in inculcating conservation ethos in societal members, especially the youngsters on how to live sustainably while caring for the rich biodiversity resources in the environment. The research demonstrates practically, how traditional festivals could be used as a social space in promoting social cohesion and unison towards the achievement of biodiversity conservation. The study has shown practical ways of undertaking environmentally friendly activities in host communities before, during and after the festival observance which can be effectively utilized by the traditional authorities and conservationists in the host communities to boost the conservation and sustainability of biodiversity. The research has shown how the traditional festivals can be succinctly adapted by policymakers and developers working in local regions as viable platforms in maintaining and enhancing the natural resources in the jurisdictions. It shows how festival organizers can mobilize sponsorship for the organization of the traditional festivals in their host communities to obtain the required logistics for environmental activities during the festival occasion.

The research also has much academic significance. It adds up to the multidisciplinary approach to ensuring biodiversity conservation globally. The study accentuates the ideals expressed in the cultural ecology theory that postulates that the culture of man has a consolidated interaction with his environment [18]. Thus, the cultural activities of a people can have both positive and negative effects on their environment and its resources. The research affirms this theory and shows in a scholarly fashion, how cultural events such traditional festivals can be harnessed positively to promote the conservation of the biodiversity resources in the celebrant communities. It describes how traditional and cultural events could be utilized to enhance and promote environmental education and activities. Also, it shows theoretically how traditional festivals can be used in bolstering the traditional conservation ethos in the members in the host communities and visitors to live in harmony with nature while engaging in safe environmental activities. It reiterates that the core objectives for the traditional festival organization could be effectively harnessed to promote and enhance the conservation of biodiversity resources in the host communities. The research emphasizes and paves an academic path in demonstrating how scholars in the field of Cultural Anthropology and Event Management could utilize traditional festivals celebrated by communities in promoting good environmental practices and environmental education that enhances biodiversity conservation.

\section{Methodology}

The research is a cultural anthropological study carried out in three local communities in Ghana (Figures 1-3). These three communities were chosen because 


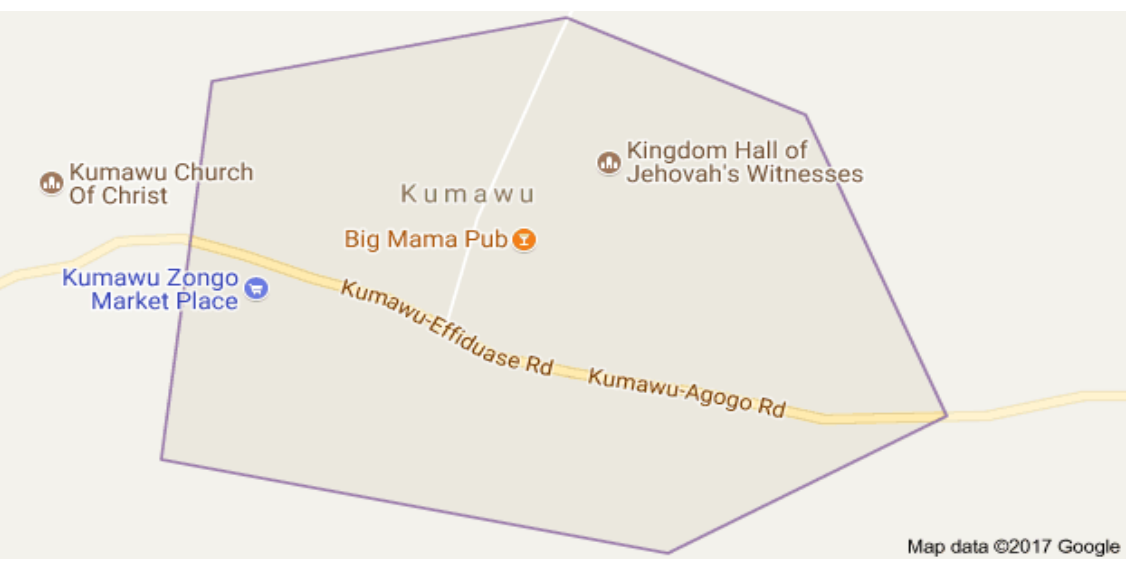

Figure 1. Map of Kumawu. Source: Google maps.

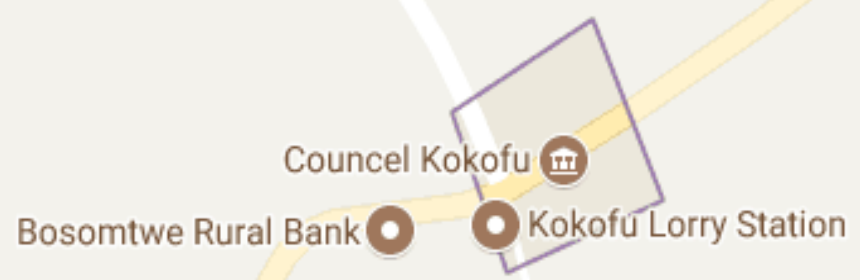

Map data @2017 Google

Figure 2. Map of Kokofu-Anyinam. Source: Google map.
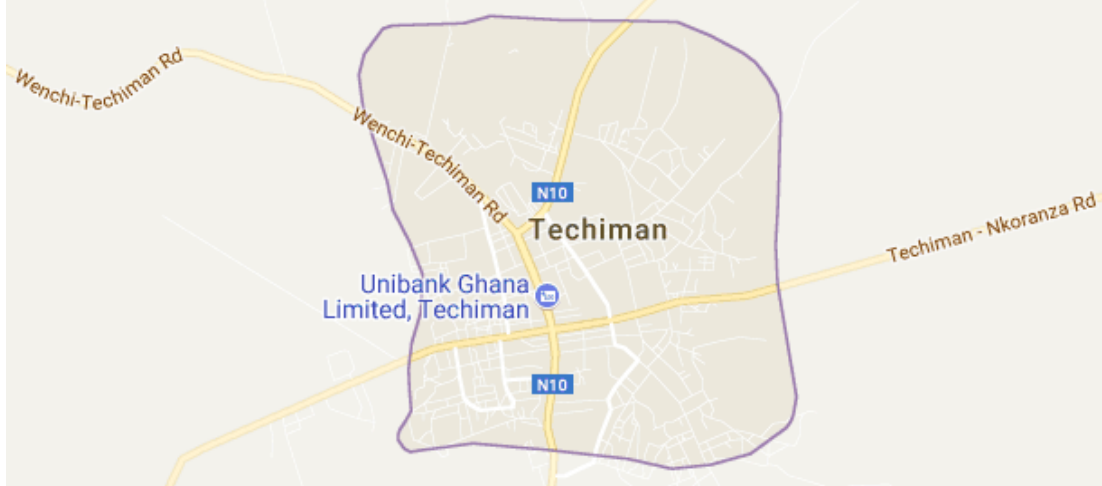

Map data @2017 Google

Figure 3. Map of Techiman. Source: Google map.

they celebrate the populous cultural festivals in Ghana. Also, they hold the longest and extravagant established traditions regarding their festivals which have strong relevance in ensuring environmental sustainability. The study was undertaken between November 2016 and July 2017 with the sole aim of investigating into how traditional festivals could be adapted for the sustainable development of biodiversity in the host communities.

The study was driven in the qualitative approach because of its attribute of 
vividly describing and comprehending phenomena in their natural settings from the perspectives of respondents who have experienced the phenomena [19]. This research approach was seen as very appropriate for the study because of its cultural and social context [20], thus, a festival event that depicts the cultural experiences of the host communities. The narrative and descriptive research methods were heavily used for soliciting the data for the research. The narrative approach aided in recording the personal lived experiences of the participants [21] regarding the traditional festivals and how they have ensured the development of the biodiversity in the environments of the host communities. These narratives from the respondents concerning the traditional festivals were necessary to help the researcher to examine and understand how the respondents constructed their meanings on how the festival events impacted on the environment in an exploratory, in-depth manner [22]. The systematic documentation of events in the descriptive research method [23] was also used to record the festival events. It helped the researcher in discerning the beliefs and practices associated with the members of the festival host communities [24]. The principles in the phenomenological study that seeks to give an interpretive account of the beliefs and practices of a group of people [25] were utilized for this study to assist the researcher in understanding how the traditional beliefs held by the people influenced the way they treated the biodiversity resources in their environment.

Sixty-six (66) purposively sampled respondents consisting of traditional authorities (Chiefs, queen mothers, traditional priests, Elders in the Traditional Councils of Techiman, Kumawu, and Anyinam), the residents of the host communities and environmentalists from the Environmental Protection Agency formed the target population (Table 1). These categories of informants were selected deliberately because they were seen as possessing the unique characteristics that would generate the required data for answering the research questions for the study [23].

A total of seven (7) Personal Interviews and twelve (12) Focus Group Discussion Interviews were conducted to generate the necessary data for the study. Personal interviews were organized for a section of the sample due to the secretive nature of some rituals and practices involved in the festival organization that was not to be disclosed publicly [19]. Yet, this sensitive data was seen by the researcher as indispensable in offering a thorough insight into the relevance of the traditional festival in promoting and protecting the biodiversity of the host communities. On the other hand, Focus Group Discussion Interviews were organized for the young and elderly residents in the various host communities after they were grouped into categories based on their age, experience, and position they occupied in their respective communities. This form of the interview was relevant for the study type because it aided the members in the respective groups to feel free in giving out information regarding the traditional festivals while others served as prompters of very salient information resulting in very interesting and prolific discussions [26]. 
Table 1. Breakdown of interviewees involved in the study.

\begin{tabular}{|c|c|c|c|}
\hline No. & $\begin{array}{l}\text { Category of } \\
\text { Interviewee }\end{array}$ & $\begin{array}{l}\text { Total No. } \\
\text { Selected }\end{array}$ & Details \\
\hline 1. & $\begin{array}{l}\text { Traditional } \\
\text { Authorities }\end{array}$ & 6 & $\begin{array}{l}\text { Three ( } 3 \text { ) chiefs and three ( } 3 \text { ) queen mothers from the } \\
\text { host communities (Anyinam, Kumawu, and Techiman) } \\
\text { were interviewed individually (Personal Interview). }\end{array}$ \\
\hline 2. & $\begin{array}{l}\text { Elders in the } \\
\text { Traditional Council }\end{array}$ & 24 & $\begin{array}{l}\text { Eight (8) elders in each of the Traditional Councils } \\
\text { (Anyinam, Kumawu, and Techiman) were interviewed } \\
\text { in Focus Group Discussion Interview sessions. }\end{array}$ \\
\hline 3. & Religious Officials & 3 & $\begin{array}{l}\text { Three (3) traditional priests in the three } \\
\text { host communities were interviewed privately. }\end{array}$ \\
\hline 4. & $\begin{array}{l}\text { Elderly Residents } \\
\text { (45 and above) }\end{array}$ & 18 & $\begin{array}{l}\text { Six (6) elderly respondents from each of the } \\
\text { three host communities were interviewed in } \\
\text { Focus Group Discussion Interview sessions. }\end{array}$ \\
\hline 5. & $\begin{array}{l}\text { Youth Residents } \\
\text { (20 years - } 44 \text { years) }\end{array}$ & 9 & $\begin{array}{l}\text { Five youths from each of the three host } \\
\text { communities were selected and interviewed in } \\
\text { Focus Group Discussions Interview sessions. }\end{array}$ \\
\hline 6. & Environmentalists & 6 & $\begin{array}{l}\text { Two Focus Group Discussion Interview sessions } \\
\text { for six (6) purposively sampled workers } \\
\text { at the Environmental Protection Agency. }\end{array}$ \\
\hline
\end{tabular}

Source: Author's construct from field survey 2016.

To aid in vividly recording the events in the traditional festivals firsthand [27], the researcher engaged in direct observations to visually glean all the relevant textual and visual data to effectively study the phenomena. A well-designed observation checklist with clear angles of observation aided in the taking note of the important features of the festivals that were directly related to the study objectives. Finally, the Interpretive Phenomenological Analysis (IPA) was used in analyzing the data generated from the study. This analytical tool helped the researcher in constructing meanings of the data from the direct perspectives of the informants [28].

Table 1 gives a thorough description of the respondents that were involved in the study. The interviewees were categorized into six. The first category is the traditional authorities who are the governing heads of the local communities were personally interviewed. They are the chiefs and queen mothers. Every community has one chief and one queen mother. In addition, the traditional authorities have their cabinet of elders who advise them and assist them in making fruitful decisions. Eight elders in each of the three traditional councils of the selected communities were interviewed in a focus group discussion. Three traditional priests who serve as religious officials in the three communities respectively were also interviewed. They are the religious officials who perform all the rituals and sacrifices required by the deities and ancestors during the festival commemoration. They serve as representatives and messengers of the deities and ancestors. The elderly members aged between forty-five years and above in the selected local communities were also interviewed in a focus group discussion. 
This was necessary because they have seen the evolvement of the festival commemoration over the years and were capable of furnishing the researcher with the relevant information regarding the festivals' activities that heighten environmental sustainability. The younger members of the local communities were also interviewed in a focus group discussion to ascertain the biodiversity conservation education that they glean during the festival eve. Finally, the environmentalists working in the conservation bodies in and around the host communities of the traditional festivals were also interviewed in a focus group discussion interview. The discussions with them were seen as very necessary because they are in charge of the conservation of the biodiversity resources in the Ghanaian environment.

\section{Results and Discussions}

This section of the paper presents a brief overview of the geographical information about the host communities while presenting and discussing the findings from the study.

\subsection{Brief Overview of Study Areas}

The research was undertaken in three local communities in Ghana, namely, Anyinam-Kokofu and Kumawu Traditional Areas in the Ashanti Region as well as the Techiman Traditional Area in the Brong Ahafo Region.

Kumawu is a small town in the Sekyere Kumawu District. Figure 1 shows the location of Kumawu off the Kumawu-Agogo Road in the Ashanti Region of Ghana. The people are mostly farmers, hunters, and fishermen. It is estimated that about $81.8 \%$ are engaged in crop farming while the remaining percentage caters for the other occupations. The town is famed because of the Bomfobiri Wildlife Sanctuary and the Kumawu Traditional Palace that serve as tourist attraction sites because of their historical and cultural significance. They celebrate the Papa Nantwi festival annually to remember the exceptional bravery of their great ancestor, Nana Tweneboa Kodua I.

Kokofu-Anyinam is a small town in the Bekwai Municipal District in the Ashanti Region of Ghana. Figure 2 shows the location of the town which is within the Bosomtwe Rural Bank and the Kokofu Lorry station in the Ashanti Region of Ghana. The town is famed primarily because it is the birthplace of the first Asante king Osei Tutu I and also due to the abundance of the Onyina (Ceibapentandra) tree in the jurisdiction. The place has a sacred place called the Kwantakese sacred grove. They commemorate the Opemso festival bi-annually to remember the birth of the Asante king Otumfuo Osei Tutu I.

Techiman is a popular town and the capital of the Techiman Municipal District. The town is the leading marketing town in the Southern part of Ghana. Figure 3 shows the map of Techiman which is off the Wenchi-Techiman Road in the Brong Ahafo Region of Ghana. The major agricultural product is the production of yam with an annual yam festival commemorated annually. Also, 
the popular Apoo traditional festival is commemorated every year to remember the bravery of Nana Akumfi Ameyaw I.

\subsection{The Core Purpose and Significance of the Traditional Festivals}

The three traditional festivals selected for the study had their core purposes. These are varied, ranging from the commemoration of historic events, honoring of ancestors and for reviving as well as promoting the cultural traditions of the host communities.

\subsubsection{Opemso Festival}

The Opemso festival is held once every two years to remember the iconic event that happened in the lives of the Asantes in the Ashanti Region of Ghana. [3] explains that the name of the festival, thus, Opemso (Courageous conqueror) is the exclusive title that was given to the first king of the Asante kingdom who was said to have taken the courageous stand to unite the seven Akan clans into the vibrant and powerful Asante kingdom. This was supported by the comment of the Anyinam-Kokofu chief who confidently said:

Our great ancestor and Lord was a valiant person who had no dread for all the enemies of the Asantes. His unique and cooperative spirit aided in uniting the various clans of the Akans to defeat all their enemies. He was the undeterred warrior who mobilized the Asantes with the Wokumapema apembeba (If you kill a thousand, another thousand would come) ideology which has been the motto of the Asante kingdom till date. The great courage he had was a powerful source of inspiration for his subjects, who, like him, demonstrated bravery and fought to establish the geographical confines of the Asante kingdom from the encroachment of the surrounding states and ethnic societies (TA-AN-PI, Personal Communication, 23/8/2016).

The traditional festival is commemorated to remember the birth of this great king in the history of the Asante kingdom. It is a remarkable event where all the chiefs in the Asante kingdom meet to recount the great conquering ability and courage of the first Asante king OtumfuoOsei Tutu I. The youths in Kokofu-Anyinam disclosed to the researcher that they learn a lot of lessons about the rich cultural heritage of the Asantes anytime they commemorate the Opemso traditional festival. In a Focus Group Discussion interview, they said:

The traditional festival is a grand occasion where we learn about the history of our people and get in-depth knowledge and understanding of the cultural heritage of the Asantes. It makes us proud of our ethnic and place identity. We learn to tread the path of our great ancestors who fought to establish our kingdom so that we can equally protect the geographical confines of our people as well as the rich Asante culture for the future progeny (YOU-AN-FGD, Personal Communication, 24/9/2016). 
The views of the youth informants correspond with the theoretical construct of [14] who admitted that festivals are primarily organized by ethnic societies to beef up their community pride and place identity. The event is organized at the birthplace of the great king at Kokofu-Anyinam in the Ashanti Region. An oral tradition narrated by the elders in the Anyinam-Kokofu Traditional Council to the researcher indicated that the great leader of the Asantes was born in a thick forest under a big Onyina (Ceibapentandra) tree. The researcher observed that the birth spot, its surrounding biodiversity species, and environment constitute a sacred gazette area where no one is supposed to enter and/or encroach. The sacred grove is called Kwantakese (The great path). It is believed by the people that the path to the birth spot of the Asante king is seen as great because it is the ancestors who led his mother Nana Gyamfuaa Manu Kutusi to give birth there. It is a taboo and a great offense for anyone to enter the thresholds of the grove to take any of the biodiversity resources. As a result, the area is full of rich great diversity of biological resources. Many of the important spiritual activities during the festival are performed at this sacred place. The numerous cultural activities are used to illustrate the historical episode of the events that systematically resulted in the birth of the great king.

Figure 4 shows the flora diversity in the sacred grove. They include diversities of Mahogany (Khayaspp), Nyamedua (Alstoniaboonei), Ahomakyem (Spiropetalumheterophyllum), Odum (Milletiaexcelsa), Nufutene (Kigelia Africana) and Onyina (Ceibapentandra).

\subsubsection{Apoo Festival}

The Apoo festival is a traditional festival commemorated by the people of Techiman in the Brong Ahafo Region of Ghana. It is an eleven-day annual event that is used in remembering a very significant historic episode in the lives and culture of the people of Techiman who were then referred to as the Bono-Manso people. The researcher investigated why the festival was referred to as Apoo. The etymological meanings were given by the elders in the Traditional Council of Techiman who were interviewed in a Focus Group Discussion. They informed the researcher that:

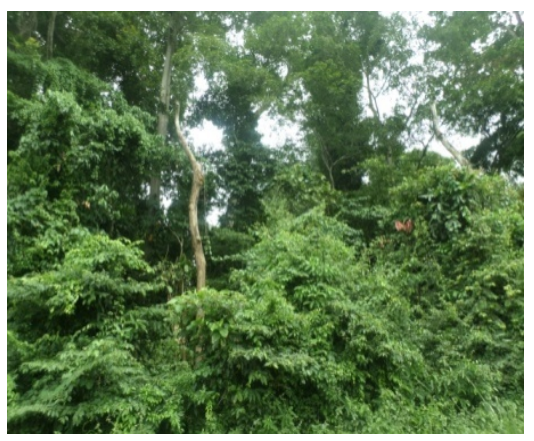

(a)

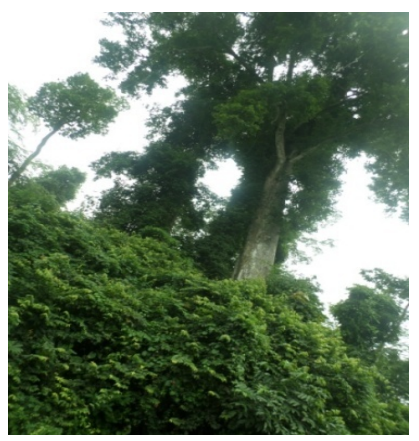

(b)

Figure 4. The flora diversity in the Kwantakese sacred grove. Source: Photographed by the researcher. 
The term Apoo is from the Bono word po which means to repudiate or reject something. Apoo gives a plural form of the repudiation, thus, of many people engaging in the act. It was first used by our great paramount chief Nana Akumfi Ameyaw I who asked a group of women who came to him at his residence during the festival eve whether they came to repudiate his actions (Momepo me mu o!). The women affirmatively responded that they came to him to repudiate the wrong things in the society. This is the whole essence of the festival, thus, meant to repudiate publicly without any fights or whatsoever, the mistakes and bad actions of everyone, including those occupying key positions in the society through songs and maxims (ELDTEC-FGD, Personal Communication, 7/8/2016).

Recounting the events that led to the celebration of the Apoo festival, the queen mother of Techiman in a personal interview gave a very extensive narration to the researcher. Important excerpts of the narration are presented below.

The traditional festival was as a result of a deadly plague that befell the people which through an oracle proved that it was the punishment from a great deity in Techiman called Sipe who hated animosities harbored in one's heart against his/her fellow. Thus, many people who held wicked thoughts about their neighbors, particularly the chief were mysteriously killed by the deity. Thus, to cause a cessation of the deadly plague, the people needed to expose the wrong deeds of their society members publicly. Thus, the then paramount chief, Nana Akumfi Ameyaw I, instituted the Apoo festival so that the members of the community could freely voice out the detestable acts of their neighbors, including those occupying high positions in the society publicly without any accusations or penalties. However, the act was to be done in a dignified and respectable manner. Therefore, the wrong acts of one's neighbor are chanted using songs and proverbs publicly in the vicinity of the culprit so that $s /$ he would know and change his/her wrong course. The festival, thus, effectively arrested the dead plague on the people since they maintained their peace with the Sipe deity. Every year, eleven days are allotted for members of the Techiman community, both the ordinary and the privileged in the society, to freely voice out their grievances and bad acts of people in a democratic manner for immediate redress. The traditional festival has sustained and enhanced the unity in the Techiman society. This unity is seen especially between the chief and the members of his Traditional Council and his subjects (QU-TEC-PI, Personal Communication, 5/8/2016).

The core objective of the Apoo traditional festival which is an event commemorated to ensure peace and unity which are pinnacles of social integration and cohesion agrees with the theoretical constructs of festivals by [3]. He admitted that traditional festivals ensure "social cohesion within families, between families and the entire society as a whole" (p. 13). 
The researcher observed various individuals and groups who chanted and paraded on the streets of Techiman during the traditional Apoo festival. Various songs that were fused with many proverbial sayings were carefully selected by the people to expose the bad attitudes of members of the society including the paramount chief. Many of these groups walked directly to the houses, workplaces, and palaces of the culprits of the wrongdoings with the aim of disclosing those disturbing acts to them.

Figure 5 shows groups walking in the streets chanting songs and proverbs as they head towards the chief's palace to expose his actions that the members of the society detest. Also, the researcher observed that many of these dancers and chanters were dressed in anonymity fashion while some wore masks. The researcher inquired the reasons behind that dress code. He was reliably informed by the residents that:

The dress code is just a mimicking of how our ancestors dressed during the Apoo traditional festival in times past. Oral tradition told us indicated that our early forebears feared of being found out and/or executed when they went to the chief's palace to voice out their grievances of his bad deeds. Thus, many of them dressed in such a way that their real identities would be hidden (RES-TEC-FGD, Personal Communication, 7/9/2016).

Figure 6 shows how people hid their identities by wearing masks as they espouse the bad deeds of others through songs and proverbs as they walk to the vicinity of the person or group of people in question.

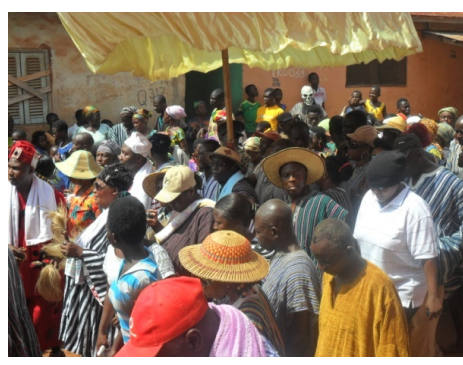

(a)

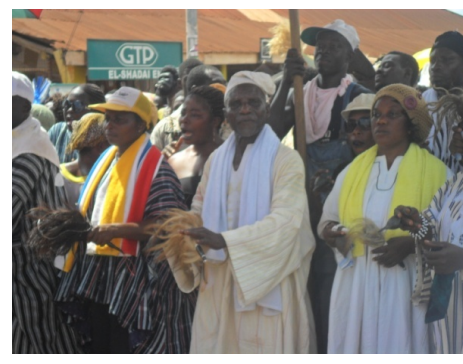

(b)

Figure 5. Celebrants at Apoo Festival. Source: Photographed by the researcher.

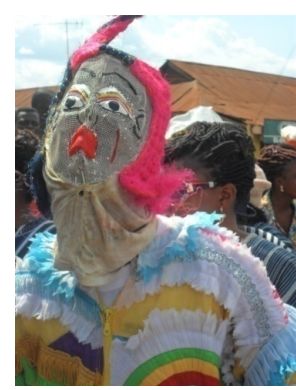

(a)

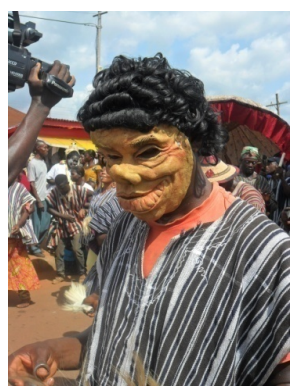

(b)

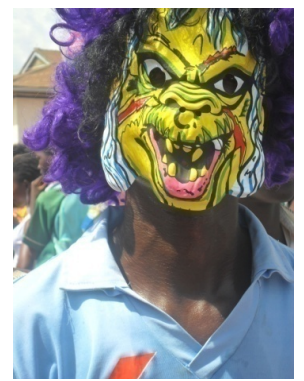

(c)

Figure 6. Dancers and chanters dressed in masks to hide their identities from the public. Source: Photographed by the researcher. 


\subsubsection{Papa Nantwi Festival}

The Papa Nantwi festival is an annual festival commemorated by the people of Kumawu in the Ashanti Region of Ghana. The festival is celebrated in the month of March every year at Akwasidae (The last Sunday of the 40-day month of the Asantes). The festival is a historic event held in honor of the exceptional bravery demonstrated by the greatest of all the ancestors of Kumawu, Nana Tweneboa Kodua I of Kumawu. Oral tradition told the researcher indicates that this great ancestor offered his life to be sacrificed to propitiate the ancestors to help the Asante Kingdom triumph over their overlord, the Denkyiras. The Gyasihene of Kumawu in a personal interview informed the researcher:

Our great ancestors reliably told me that there was a great animosity between the Asantes and the Denkyiras. Because the latter had a great number of warriors, they ruled over the Asante people, greedily taking their lands, farms, and freedom. Therefore, the then Asante king, OtumfuoOsei Tutu I, united the seven Akan states to wage war against the Denkyiras to gain their autonomy and ultimate independence. Fortunately, at that time, a very powerful traditional priest called Okomfo Anokye assured the Asante king of victory over the Denkyiras only after a human sacrifice of one of his chiefs has been offered to please the deities and the ancestors. With great valor and selflessness, our courageous ancestor, Nana Tweneboa Kodua I gave himself up to be sacrificed so that the Asantes gain victory over the Denkyiras during the war. Right after his sacrificial death, the famous traditional priest, Okomfo Anokye, conjured the Golden stool from the skies and gave it to the Asante king. This stool is believed to be the soul and unifier of the Asante people. The war between the Asantes and the Denkyiras ensued and as prophesised by Okomfo Anokye, the Asantes defeated the Denkyiras and gained their freedom. Since that day, on the eve of every March annually, the Papa Nantwi festival is organized to mark the iconic bravery, selflessness and patriotic spirit exhibited by Nana Tweneboa Kodua I (TA-KU-PI, Personal Communication, 4/3/2016).

The elders interviewed in the Focus Group Discussions also made similar narrations of the events that led to the celebration. The festival is a celebration of the well-fulfilled life of the great ancestor of Kumawu, Nana Tweneboa Kodua I. The elders explained the events that are undertaken during the festival, which was also observed by the researcher:

The traditional festival is marked by several cultural events, iconic amongst them is the cutting of a part of the big cow that is slaughtered to appease the souls of the Asante ancestors. Courageous persons are to cut parts of the meat amidst beatings from the crowd who are stationed around the cow meat. After getting hold of the cut meat, the person is supposed to run to a certain demarcated spot till he is free from any form of beating. It takes real strength and courage to partake in this cultural event that symbolizes strength, valor, and courage of their great ancestor, Nana Tweneboa Kodua 
I (ELD-KU-FGD, Personal Communication, 3/3/2016).

These revelations from the study regarding the core aim of many traditional festivals correspond with the view of [5] that traditional festivals are used as platforms for re-enacting the historical events that happened in the history of communities. This is true in the case of the Papa Nantwi festival of the people of Kumawu who use the event to remember the gallantry of their great ancestor Nana Tweneboa Kodua I while engaging in cultural events that demonstrates how to imitate his great valor.

A video of the cultural events at the Papa Nantwi festival on the bravery test can be watched at https://www.youtube.com/watch?v=VsH-6uTPVJU. The youth in the Kumawu society disclosed that they are taught many moral lessons during the festival season. They are instructed on their cultural heritage, especially, the norms, moral values, and beliefs. They learn the need to demonstrate courage in times of distress and societal unrest. The youths interviewed in the focus group discussion informed the researcher of the benefits they earned from the festival. They said:

We learn many lessons about our culture during the festival event. We abreast ourselves with many customs associated with the Asante kinship. More importantly, the beautiful history and behavioral attributes of our great ancestor, Nana Tweneboa Kodua I are espoused during the festival occasion. This bolsters the appreciation we have for him and we learn to mimic his steps of exceptional gallantry and patriotic spirit for our society and country (YOU-KU-FGD, Personal Communication, 26/2/2016).

The cultural value training the youth of Kumawu mentioned that they gained from the Papa Nantwi festival theoretically concur with the view of [15] that festivals are cultural events that are used as mediums for creating and sustaining community values that are seen as indispensable in building the societies. Thus, when the youth attend traditional festivals, they learn many important values which help them to develop personally while assisting them in fully participating in activities geared toward the development of societies.

\subsection{Aspects of the Traditional Festival Commemoration That Ensures the Sustainable Development of the Biodiversity of the Host Communities}

A critical evaluation of the three traditional festivals selected for the study shows that they all have aspects of the cultural events that directly and/or indirectly promotes the sustainable development of the host communities. These aspects have been discussed in the ensuing headings.

\subsubsection{Demarcation of a Tract of Land and its Resources as Sacred for the Remembrance of an Iconic Personality That Led to the Festival Commemoration}

The researcher observed that in all the three host communities, particular tracts of lands and their biodiversity were earmarked as sacrosanct by the people. 
These spots were directly related to the festival organization and they also played very significant roles in the iconic figures of their societies being remembered. For instance, the people of Anyinam-Kokofu have earmarked the Kwantakese forest tract, as a sacred grove because it is the birth spot of the Asante king, Opemso Otumfuo Osei Tutu I. As such, the place is viewed as sacred. Likewise, the Akumfi Ameyaw I Amanfo Mu at Techiman in the Brong Ahafo Region of Ghana is a gazetted area that is not supposed to be entered and its biodiversity resources tampered with. The researcher was hinted by the respondents at Techiman that it is the spot where the great paramount chief, Nana Akumfi Ameyaw I who instituted the Apoo festival died and was buried. Therefore, because of deep reverence for him, the entire area is not supposed to encroach. It is believed by the people that the place is the haven for the ancestors of the Techiman community.

Figure 7(a) and Figure 7(c) below show the entrance gate of the Akumfi Ameyaw I Amanfo mu (Sacred Grove). It shows the traditional symbol of swords referred to as Akofena (War Swords). These war swords embossed on the gates traditionally symbolize protection given by the deities. Thus, its representation tells the people that the place is sacred and under the heavy vigilance and security of the deities and ancestors. As such, its territories are not supposed to be encroached. In addition, the people of Kumawu have also reserved the Bomfobiri spot which has now been converted to a wildlife sanctuary and all its biodiversity resources are viewed as sacred. The place is believed to be the dwelling place of the great ancestors of the Kumawu town. These sacred areas and their

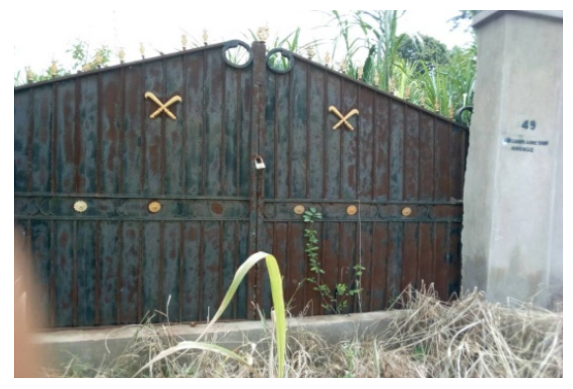

(a)

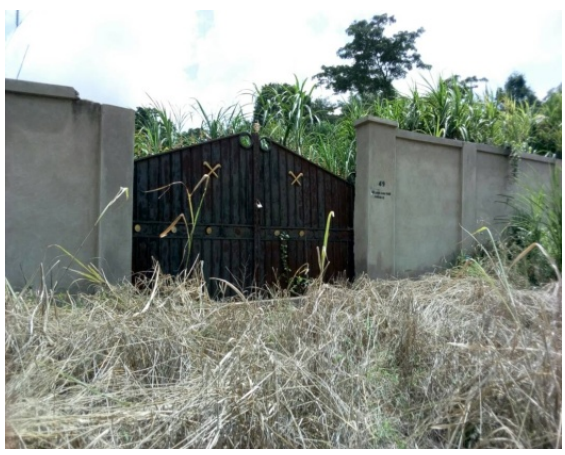

(c)

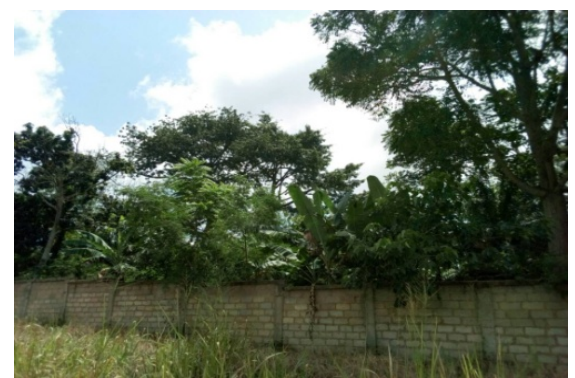

(b)

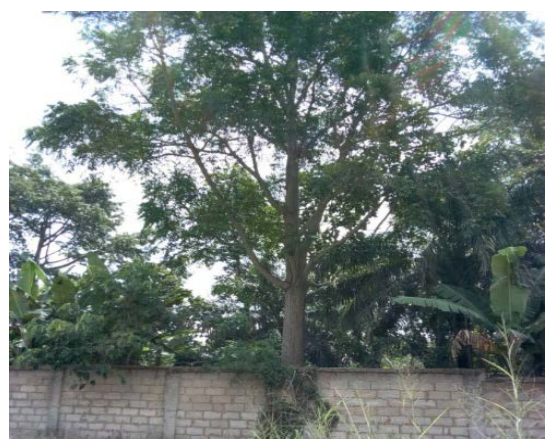

(d)

Figure 7. The Fenced Nana Akumfi Ameyaw I Amanfo mu (Sacred Grove) at Techiman, Brong Ahafo Region, Ghana. Source: Photographed by the researcher. 
biodiversity resources have been protected as a result of the traditional festivals that are linked to them. The sacred spaces give the people a sense of belongingness to their societies and provide a cementing relationship between them and their ancestors as noted by [29]. Owing to their conservation, the sacred gazette areas are pregnant with a great diversity of biological species of fauna and flora with different ecosystems as shown in Figure 7(b) and Figure 7(d). The researcher observed that it is the presence of the sacred spots in the host communities that have safeguarded their rich biodiversity and have offered the communities timely and stable rainfall patterns, bounteous agricultural harvests and supplied them with the medicine for curing diverse ailments. This realization agrees with the views of [30] and [31] who highlighted that sacred groves offer great services to the people, including boosting their agricultural yield while offering them herbal medicine as a cure for their ailments. This indicates that the deliberate demarcation of certain tracts of land as sacrilege because of their affiliation to iconic figures in local communities who are remembered during particular traditional festivals assists in the conservation of the biodiversity in the host communities.

\subsubsection{The Belief That the Spirits and Deities Must Be Pleased before the Festival Commences}

The people believe that the commemoration of a successful festival event depended largely on the deities in their communities. These deities reside in biodiversity resources in the environment such as in the large tree species, water bodies, sacred groves and thick forests. Thus, the entire society ensures that the sanity of the habitats of the deities is maintained. It was realized in the interviews and observations that before the traditional festivals commenced, there were various activities that the community members undertook in this regard. These activities were environmental and helped in the development of the biodiversity in the host communities. The researcher observed that the entire members of the communities, including the traditional authorities, engaged in these environmental activities. It was interesting to notice how the elderly members of the communities rigorously partook in the environmental cleansing and sanitation as well as in the tree planting activities. The elders interviewed in a Focus Group Discussion Interview disclosed that:

Our deities are those who overcome all forms of hindrances (Spiritual) that may disrupt the smooth celebration of our festival. Therefore, before the festival begins, we always make sure that we have fully honored their will. One important will of the deities is for us to maintain the cleanliness of the town and the engagement in activities that would inure to societal growth, such as tree plantations, de-silting of choked gutters and clearing of all forms of refuse. It is an obligation for all of us, including the elderly members who are required by the gods to set precepts for the young ones to follow to engage in the environmental activities undertaken during the festival period (ELD-AN-FGD, Personal Communication, 4/10/2016). 
The traditional authorities mentioned that engaging in environmentally friendly activities during the pre-festival period attracts benevolent spirits to assist the members of the society in making a fruitful festival celebration. The traditional priest at Techiman hinted the researcher that good spirits are attracted to clean surroundings with a serene atmosphere which is made possible via the plantation of several diversities of flora species. This belief is very high among the community members including the youth. No wonder the researcher noticed a massive involvement of the youth during the pre-festival environmental activities in the Techiman district. This observation of engaging in environmentally healthy activities correlates with the view of [9] who admitted that festival commemoration (directly or indirectly) promote the ideals of sustainable development through its campaign for environmentally protective and/or preservative activities. It was noted in the study that the host communities for traditional festivals are always in their best state environmentally during the eve of festival commemoration.

\subsubsection{The Belief in the Return and Visit of All Ancestors to the Host Communities during the Celebrations of the Traditional Festivals}

As vigil policing agents and perpetual stakeholders in community development, the ancestors of the host countries of traditional festivals are believed to spiritually visit their communities which they left behind after their physical passing. As guests to their former communities, they are very keen to see the upkeep of the environment and its biological resources. Interestingly, the local people hold the belief that the ancestors are charged with power from the supreme deity either to reward or punish. Therefore, if society members rigorously engage in activities that preserve the biodiversity in the environment, the ancestors are pleased and they would be more willing to bless society members with a successful festival. The views of the elderly members in one of the study areas regarding the ancestors' huge presence during the festive occasion were expressed to the researcher:

The ancestors of our community come and stay with the community members during the entire period of the festival observance. They detest unclean surroundings and the absence of the trees that they formerly enjoyed their shades as well as the decline in the diversities of animals like the birds that they heard their songs. Therefore, we do very well to make sure that the entire society is cleansed and the biodiversity is replenished so as not to experience their anger. Our society needs their benediction to develop and therefore, we do what they like which is conserving and protecting the environment and its resources (ELD-AN-FGD, Personal Communication, 18/9/2016).

This view expressed by the respondents clearly shows their belief that the ancestors take great cognizance of activities that are undertaken in their societies and are in fact, "spiritual policemen" as [32] opined. Thus, the comeback of the 
ancestors during the traditional festival celebration aids in the enrichment and development of the biodiversity in the environment which they are keenly interested as a sign of honoring them [7].

\subsubsection{The Traditional Festivals as Platforms for Reiterating Taboos and Values That Help in the Development of Biodiversity}

The study affirms the assertions of [1] that traditional festivals are occasions where the community values and taboos are highlighted and strengthened. The researcher noticed that the traditional councils in the three local communities under study used the festival celebration as platforms in educating the society members about the accepted values of the community as well as the community prohibitions in the forms of taboos that must not be breached. Many of these accepted community values and taboos help in the development of biodiversity. The traditional authorities informed the researcher that:

The festival period is a great opportunity where we educate the young ones and foreign residents of our land, the accepted moral values, and taboos in our community. Through the festival program, we emphasize and reiterate the do's and don'ts in the community. For instance, we tell them the taboos associated with the plants, animals and water bodies in our community. We emphasize with historical evidence, the environmental values that are accepted, cherished and held in high esteem by the ancestors. One cardinal community value is living in harmony with nature, caring for the things of nature and treating these biodiversity resources as active members of our society (TA-AN-FGD, Personal Communication, 21/9/2016).

The environmental education that is carried out during the festival period bolsters the solidarity and allegiance of the members of the society to the accepted ideals, values and norms in the society. This notification of the study agrees with the opinion of [2] that traditional festivals are tools that enhance social integration that unites society members toward living by the accepted values in the society. After the festival observance, the society members are well instructed on best environmental practices and attitudes that need to be exhibited. Recalcitrant members of the society who fail to abide and live by these sound environmental ethics that enhances biodiversity are punished in the society by the traditional council.

\subsubsection{The Maintenance of Good Place Identity to Visitors through the Engagement in Environmentally Friendly Activities}

The celebration of the traditional festival throws a spotlight on the host community. Many visitors from all walks of life visit the host community during the festival observance period. These people construct their perspectives about the society they have toured during the festival commemoration. Therefore, the traditional authorities and elders in the host communities ensure that they maintain a good place identity during the festival period. This place imagery is very important to every member of the society, including the young ones. In a Focus Group 
Discussion Interview with the youth in one of the study areas, they told the researcher that:

Many people from the cities and other urban centres, visit our town during the festival period. These people construct their general outlook of our community from what they see, especially in the physical environment. Therefore, if they realized that we have poor sanitation, cut down all our trees and destroyed the purity of our water bodies, they would construct bad place identity about us while speaking ill of us to others. Because we love our community and are proud that we are the organizers of this great festival [making reference to the Opemso festival], we help in developing and shaping the environment and its resources. All of us assist in clearing all forms of debris, plant trees, and clear all weedy areas to make our community look nice. This would make the visitors form good ideas about our society (YOU-AN-FGD, Personal Communication, 7/8/2016).

Due to the great desire of maintaining good place identity for their communities, some wealthy members of the community volunteered and provided the resources or logistics that were needed to engage in environmentally friendly activities such as cleaning, tree plantation, sweeping and so forth. This realization of the three festivals studied concurs with the assertions of [33] that festival celebrations are used as avenues for enhancing the environmental conditions of host communities through the planting of trees, renovation of old structures and parks. Also, the notifications of massive cleaning exercises in the host communities validate the view of [1] that traditional festivals promote cleanups and fix-ups, improving the buoyancy of the infrastructure and environment [4] [12]. Some of the divisional chiefs as well as the local people who had enjoyed greener pastures in foreign lands and had returned to home financed the purchase of the cleaning detergents, brushes, cutlasses, seedlings of indigenous plant species, water cans, refuse and dustbins. Others bought drinks and meals to refresh the members who engaged in the environmental activities. Indeed, festival celebrations attract sponsorship from individuals, companies, and organization [1]. The elderly women, who were tasked to prepare free meals in one of the study areas, did it with great joy. The jubilant crowd who engaged in the environmental activities willingly demonstrates their strong desire to maintain their community pride and place identity. These findings corroborate the notification of [4] that maintaining a good place identity and image branding is very important to host communities of festivals. As such, they are more willing and determined to live sustainably to assist in developing and enhancing their biodiversity, thereby heightening the pride and place identity of their communities.

\subsection{Adaptation of the Traditional Festivals for the Promotion of Sustainable Development of the Biodiversity of Host Communities}

The revelations from the study indicate that traditional festivals hold a very great 
and wonderful potential in helping in the development of the biodiversity of the host communities. This can be carried out if the planners of the festival events heighten the environmental education during the festival period while rebranding and adapting the festival to green the environment. Pragmatic measures need to be put in place to ensure that the traditional festivals are well utilized to promote the ideals of conservation and sustainability of the biodiversity in the environment. The views expressed by the respondents affirm this. For instance, the traditional authorities mentioned that heightening environmental activities during festival celebrations would require the support of the relevant ministries such as the Ministry of Lands and Forestry. When the researcher inquired how relevant bodies could support the efforts of the host communities in the development and enhancement of the biodiversity in their environment, the traditional authorities said:

The Forestry Commission and the Environmental Protection Agency must provide the required logistics to assist the local communities in the environmental cleansing and tree planting exercises they undertake in their communities. This would prepare and motivate our people to engage in these activities. This aid is crucial because most of the local communities are impoverished. (TA-KU-FGD, Personal Communication, 4/8/2016).

The sponsorship of festival celebrations by external agencies depends on how well the festival has been planned. For instance, [14] suggested that for traditional festivals to receive funding from companies and organizations, the festival planning committee must have qualified professionals who can cleverly plan the proceedings of the event. Thus, the lack of proper sponsorship for the festival event as suggested by the elders indicate that probably the planning committees for the three traditional festivals were not professionally qualified to perform that task. The managerial team of the traditional festivals must carefully sell the innovations and service components of the festival [13] so as to win sponsors. This would even stir competition among the sponsors as noted by [5].

Aside from this initiative suggested by the traditional authorities, the conservationists added that the Forestry Commission and the Environmental Protection Agency needed to do more in terms of collaboration with the local communities' programmes for the traditional festivals. They must properly liaise with the festival organizers to be able to draw a very effective festival program that is directed at relaying environmental education. The conservationists mentioned that:

The Forestry Commission and the host communities must sit down and plan with the festival organizing committees of the host communities. This would help the planners of the event to incorporate the required education on biodiversity conservation, which is appropriate to the local context to be offered by the Environmental Protection Agency or the Forestry Commission (CON-EPA-FGD, Personal Communication, 7/9/2016). 
This proper collaboration between the conservation bodies and the host communities would be very keen to the development of the biodiversity in the regions. For instance, the head of one of the conservation bodies suggested that the collaboration would help the Forestry Commission to offer to the local communities, the seedling of the flora species that need plantations as well as the areas in protected areas that are degraded and need to be replanted. This is crucial because the local people may not know the critically endangered, endangered and threatened species that need a great boost in the plantation as dictated by the IUCN Red List.

Moreover, the conservationists also suggested that the Environmental Protection Agency and the Forestry Commission can take advantage of the festival occasion to organize workshops and seminars on best farming, hunting, and fishing practices as well as the need to implement the current scientific methods to the farmers, hunters and fisher folks in the host communities. These three professions are given much attention during such festival celebrations [5]. Because of the holidaying that often mark the festival period [34], a larger number of the farmers and fisher folks would be available for such environmental awareness and the provision of technical know-how on the modern scientific methods that ensure the sustainability and conservation of biodiversity.

[16] mentioned that traditional festivals always contain the "rites of competition". Some of the young members of the society suggested that the competitions that are often organized during the festive occasion can be tailored for environmental training and education. When the researcher suggested this idea to the traditional authorities in the host communities they applauded it wholeheartedly. They also added that some youth in the community can be quizzed on their knowledge of the pragmatic strategies for conserving and sustaining the biodiversity in their communities. The conservationists suggested that the moderator of the biodiversity conservation quiz should use the platform to elucidate the negative and bad farming and fishing practices that defeat the ideals of conservation and sustainability. Also, the elders in the communities indicated that the philosophical meanings in the traditional ecological knowledge evident in the folk knowledge in stories, folktales, proverbs, myths and so forth should be espoused during such quiz sessions.

Owing to the fact that festivals are "full of rituals of entertainment" [34], the young adults interviewed in a focus group discussion suggested that the organization of dramatic performances to re-enact how the ancestors conserved the biodiversity in the environment and their sustainable ways of living would be interesting and lesson-laden. This, the researcher believes would fill the entertainment void while instructing the society members and visitors on the need to live in harmony with nature. Interestingly, fictitious themes and stories with the names of the known ancestors in the society as the main characters of the environmentally driven drama sessions can be held during the festival season for environmental education. 
[9] cautions that the activities in festival celebrations if not carefully monitored, may result in negative effects towards the environment and its biodiversity resources. He explains that the massive turn out of people to the festival venue may result in increased environmental, noise and vehicular pollution and exacerbated waste which may get out of hand. With the three traditional festivals in focus, the researcher noted that constant announcements were given during the festival celebration period on the need to maintain sound environmental cleanliness which would please the ancestors while promoting the healthy state of the people. After each day's event, the researcher observed that the festival organizers and the elders in the traditional councils cleverly mobilized the local people to gather all forms of waste which were deposited in waste bins at the festival venue. These waste bins were supplied by a private waste disposal company in the country. Yet, they were woefully inadequate. However, the action was the community drive for maintaining a good place identity and an exhibition of deep respect for the ancestors as well as the elderly members of the community who were seen spearheading the environmental cleansing activities.

In addition, there were restrictions imposed on the movement of vehicles to the festival venue and other places that were of tourist interest and attraction. For instance, at Anyinam-Kokofu during the Opemso festival, the researcher noted that the road from Kokofu to Anyinam was highly restricted to only the president of the land and his entourage while all the road networks to the Kwantakese sacred grove, the Anyinam Traditional Palace and the house of the mother of Otumfuo Osei Tutu I were completed blocked from all vehicular entry. The researcher observed that the chiefs sat in their palanquins while the elders and other important figures in the society walked by foot. This greatly eased human and vehicular traffic while reducing the pollution from the fumes of the vehicles that plied the roads of the host communities. Festival adaptations aimed at enhancing the development of biodiversity must consider pragmatic ways of arresting all forms of activities that would likely result in the loss of biodiversity. The setting up of a festival monitoring team to oversee and arrest all forms of environmental malfeasance through the mapping up of proactive strategies can result in a very fruitful, memorable festival celebration that enhances the development of the biodiversity in the host communities.

\section{Conclusions}

The research was aimed at finding proactive ways of adapting traditional festival celebrations in helping in the development of the biodiversity in the host communities. The conclusions that have been drawn from the study are very affirmative and validate traditional festivals as viable platforms for the development of biodiversity. The core principles for the traditional festival commemoration could be heightened with the principal ancestors who are the focus of the festival events as iconic figures in biodiversity conservation and sustainability. Due to the strong interest of these ancestors in the welfare of their communities, they 
can be used as mentors for the propagation of good moral values and sustainable living that enhanced the state of the biodiversity in their environment.

The belief that the deities in the community must be pleased before the organization of the festival also assists in the development of the biodiversity in the environments of the host communities. The habitual places of these deities that are primarily within the spheres of biological components such as large flora species, water bodies, sacred groves and thick forests bolster their conservation and sustainable use. Also, their serenity is guaranteed as the belief bestows an obligation on all community members to engage in environmentally friendly activities that would aid in attracting the favor of the deities who would ensure the protection of the people and the eventual success of the festival event.

The belief in the return of the ancestors during the festival period also promotes the development of the biodiversity in the host communities. As caretakers of biodiversity, the ancestors are revered and respected by community members who try to please the ancestors by undertaking environmentally friendly activities and exercises that would put the biodiversity resources in their communities in good shape. The early forebears of the host communities had resilient moral values that advocated for the protection of the environment and its biodiversity resources. Also, taboos that prohibited negative and unfriendly environmental activities were instituted by the deities that the early forebears left for the present generation to uphold. These taboos assist greatly in the conservation of biodiversity in the host communities. The traditional festival events are used as opportunities for reminding and informing society members, especially the younger generations on the need to cultivate the expected sound moral values while observing the taboos which are environmentally friendly. The maintenance of a good place identity also motivates the members of the host communities to engage in environmentally friendly activities that develop the biodiversity in their jurisdiction to earn a good place image from visitors and those who tour their communities during the festival period.

Finally, traditional festivals can be enhanced and adapted to promote the ideals of conservation and sustainability of biodiversity through effective collaboration between the host communities and the conservation bodies. The latter must find ways of assisting the festival organizers in planning for the festival while incorporating environmental education and awareness creation in the activities drawn for the festival. They must provide expert guidance on the environmental activities that are to be undertaken by the host communities to promote and develop the biodiversity in their environment. Also, the conservation bodies must supply and/or seek sponsorship to be able to provide the needed logistics that would be used by the host communities in their environmental activities during the festival. The stakeholders in the host communities, especially the traditional authorities must ensure that well-qualified persons are appointed as part of the festival planning and management committee. This would enable the team to draw a very good festival program to attract sponsors for the event while using the traditional festivals to promote the ideals of conservation of biodiversity. 
A monitoring team should be set up within the festival planning and management committee to oversee the entire festival event, especially activities that would mar the state of the biodiversity in the host communities. The team must devise effective strategies for arresting all forms of environmental malfeasance such as waste and pollution of the environment. Indeed, the research has demonstrated that traditional festivals, though, are cultural events, when they are well adapted and enhanced, they could promote the ideals of conservation in the attitudes of the attendees and thereby developing the biodiversity of the host communities.

\section{Areas of Further Research}

The limitations of the study were the lack of key information on how the conservation agencies assisted in the provision of funding, logistics, and training during the organization of traditional festivals to boost environmental education as well as biodiversity conservation. A further research needs to be conducted with the sole objective of looking into how the conservation agencies can enhance their involvement in the commemoration of traditional festivals for the promotion of environmental sustainability education. In addition, a future study must delve into how to ensure proper economic planning and budgetary allocations for the successful organization of traditional festivals to increase the economic development of the celebrant communities.

\section{Acknowledgements}

The researcher thanks dearly the traditional authorities and people of Techiman, Kumawu and Anyinam for their warm reception, cooperation and assistance they offered for the success of this research project. Also, the researcher thanks Ophelia Addai and Michael Amponsah, the research assistants who aided the researcher in conducting the numerous personal and focus group discussion interviews. Special thanks go to the conservationists at the Bosomtwe Forest Reserve and the Bomfobiri Wildlife Sanctuary for providing a lot of insight to the researcher on the study.

\section{References}

[1] O’Suvillan, D. and Jackson, M.J. (2002) Festival Tourism: A Contributor to Sustainable Local Economic Development? Journal of Sustainable Tourism, 10, 325-342. https://doi.org/10.1080/09669580208667171

[2] Crespi, V.M. and Richards, G. (2007) The Meanings of Cultural Festivals. International Journal of Cultural Policy, 13, 103-122.

[3] Adom, D. (2016) Cultural Festival as a Salient Tool for Strategic, Holistic and Sustainable Rural Development in Africa: The Case of the Opemso. Festival of the Asantes of Ghana. Advances in Social Sciences Research Journal, 3, 4-20. https://doi.org/10.14738/assrj.311.2249

[4] Quinn, B. (2006) Problematizing "Festival Tourism": Arts Festivals and Sustainable Development in Ireland. Journal of Sustainable Tourism, 14, 288-306. https://doi.org/10.1080/09669580608669060 
[5] Odotei, I. (2002) Festivals in Ghana: Continuity, Transformation, and Politicization of Tradition. Transactions of the Historical Society of Ghana, New Series, No. 6, 17-34N.

[6] Richards, G. and Hall, D. (2000) Tourism and Sustainable Community Development. Routledge, London, 336. https://doi.org/10.4324/9780203464915

[7] Bonye, Z.S. (2008) Harnessing Synergies: The Role of Traditional Institutions in Natural Resource Management in the Tallensi/Nabdam District, Upper East Region. Master's Thesis, University of Development Studies, Tamale, Ghana. http://www.udsspace.edu.gh

[8] Ngoma, R. (2001) African People and Culture: Southern African. Oceanic Publications, 58.

[9] Cudny, W. (2013) Festival Tourism-The Concept, Key Functions, and Dysfunctions in the Context of Tourism Geography Studies. Geographical Journal, 65, 105-118.

[10] Adom, D. (2016) Asante Indigenous Knowledge Systems: Repositories of Conservation Ethics for Ghana's Biodiversity. Proceedings of the Academic Conference of Interdisciplinary Approach, Vol. 7, No. 2, Sokoto, 4 August 2016, 8-36.

[11] Adom, D., Kquofi, S. and Asante, E.A. (2016) The High Impacts of Asante Indigenous Knowledge in Biodiversity Conservation Issues in Ghana: The Case of the Abono and Essumeja Townships in Ashanti Region. British Journal of Environmental Sciences, 4, 63-78.

[12] Asante, E.A., Adom, D. and Arthur, N.A.P. (2017) Promoting Environmental and Infrastructural Development through Selected Cultural Practices. 6th International Conference on Infrastructural Development in Africa, 561-579. http://www.icida.knust.edu.gha/

[13] Lyck, L., Long, P. and Grige, A.X. (2012) Tourism, Festivals and Cultural Events in Times of Crisis. Copenhagen Business School Publications, Denmark, 190.

[14] Fjell, L. (2007) Contemporary Festival: Polyphony of Voices and Some New Agents. Studying in Croatia, 19, 129-149.

[15] Derett, R. (2003) Making Sense of How Festivals Demonstrate Community's Sense of Place. Event Management, 8, 49-58. https://doi.org/10.3727/152599503108751694

[16] Fallasi, A. (1987) Festival: Definition and Morphology. In: Falassi, A., Ed., Time Out of Time, University of New Mexico Press, Albuquerque, 1-10.

[17] Tutu, K.A., Ntiamoah-Baidu, Y. and Asuming-Brempong, S. (1993) The Economics of Living with Wildlife in Ghana. Report Prepared for the World Bank, Environmental Division, 85.

[18] Gunn, M.C. (1980) Cultural Ecology: A Brief Overview. Nebraska Anthropologist, 149, 18-27. http://digitalcommons.unl.edu/nebanthro/149

[19] Leedy, P.D. and Ormrod, J.E. (2010) Practical Research: Planning and Design. 9th Edition, Pearson Education, Inc., Upper Saddle River, 67.

[20] Denzin, N.K. and Lincoln, Y.S. (1994) Handbook of Qualitative Research. Sage Publications, Thousand Oaks, 1-17.

[21] Etherington, K. (2013) Narrative Approaches to Case Studies. 1-6. http://www.keele.uk/

[22] Trahar, S. (2009) Beyond the Story Itself: Narrative Inquiry and Autoethnography. Intercultural Research in Higher Education, 10, 1-22.

[23] Fraenkel, J., Wallen, N. and Hyun, H. (2012) How to Design and Evaluate Research in Education. 8th Edition, McGraw-Hill Companies, New York, 707. 
[24] Burns, R.B. (2000) Introduction to Research Methods. SAGE, London, 613.

[25] Pietkiewicz, I. and Smith, J.A. (2014) A Practical Guide to Using Interpretative Phenomenological Analysis in Qualitative Research Psychology. Psychological Journal, 20, 7-14.

[26] Pope, C., Ziebland, S. and Mays, N. (2000) Qualitative Research: Analysing Qualitative Data. British Medical Journal, 320, 114-116.

https://doi.org/10.1136/bmj.320.7227.114

[27] Kumekpor, K.B. (2002) Research Methods \& Techniques of Social Research. SonLife Printing Press and Services, Ghana, 304.

[28] Smith, J.A. and Osborn, M. (2008) Interpretive Phenomenological Analysis. In: Smith, J., Ed., Qualitative Psychology, A Practical Guide to Research Methods, SAGE, London, 53-80.

[29] Ampili, B.K. (2012) Sacred Groves and Conservation. Vishakhapatnam-53003, Forest Department, Andhra Prahesh, 1-15.

[30] Ormsby, A. (2013) Analysis of Local Attitudes toward the Sacred Groves of Mehalaya and Karnataka, India. Department of Environmental Studies, Eckerd College, St. Petersburg. http://www.conservationandsociety.org

[31] Mensah, O.S. and Amoah, S.T. (2013) Co-Managing Ecosystem Services of Forest Reserves in Ghana: The Case of the Bobiri Forest Reserve in Kubease in the Ashanti Region of Ghana. http://www.udsspace.uds.edu.gh

[32] Adom, D. (2014) General Knowledge in Art for Senior High Schools. Adom Series Publications, Kumasi, 427.

[33] Janniskee, R. (1996) Historic Houses and Special Events. Annals of Tourism Research, 23, 398-414.

[34] Cudny, W. (2016) Festivisation of Urban Spaces. Springer Geography, Springer International Publishing, 15V. https://doi.org/10.1007/978-3-319-31997-1 